\title{
原子炉用高張力鋼溶接継手の高温引張おちび クリープ・ラプチャ試験*
}

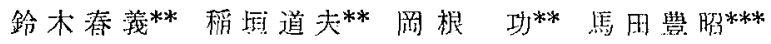

\author{
A Study on High Temperature Tensile and Creep Rupture \\ Tests of Welded Joints of High Strength Steels for \\ Nuclear Reactors*
}

By Haruyoshi Suzuki,** Michio Inagaki,** Isao Okane,** and Toyoaki Bada***

\begin{abstract}
High temperature tensile and creep rupture properties of six low alloy high strength steels were investigated for base metals and welded joints which were made with covered electrodes. Test steels were all $30 \mathrm{~mm}$ thick, four HT 60 (three normalized and one quenched \& tempered) and two HT 70 quenched \& tempered steels which were produced experimentally for nuclear pressure vessels.

The results are that:

(1) The high temperature tensile and rupture strengths of welded joints were generally inferior to those of base metals.

(2) The tensile strength of both base metals and welded joints began to decrease at $300^{\circ} \mathrm{C}$ for quenched \& tempered HT 60 and HT 70 steels, and at $350^{\circ} \mathrm{C}$ for normalized HT 60 steels.

(3) The rupture of tensile specimens of welded joints was generally located in base metal at lower temperatures, and in weld metal at higher temperatures.

(4) Generally, higher creep rupture strengths were observed for steels with higher tensile strengths at high temperatures.

(5) As far as the present test steels are concerned, normalized steels seem to have better high temperature strength than quenched \& tempered steels.
\end{abstract}

\section{1．緒言}

従来，米国などの原子炣用圧力容器仙は切久じん性の 良好な軟鋼またはボイラ用鋼などが使用されているが， 原子炉用高張力鎆之してはまだほ上んど開発されていな い. 日本溶接協会原子力研少委員会で注昭和 35 年.度原子 力局補助金研品として「原子炉用高張力錭の溶接に関す る研究」を行なった。これはこの方面の総合的な開発研 究としては，わが国始めてのこてろみである，本研究は この研究汇関連して行なわ机たすのである。

原子炉用高張力鋼の性能としては，上くに切欠じん 性, 高温性能扔よび溶接性の三者を同時に満足するよう なものが望まれる，また原子炀特有の問題として熱中性

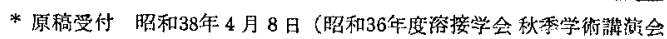
に招いて登表)

**正員金属材料技術研犯所 Member, National Research Institute for Metals Member,

***正員 富士制鉄中央研㠾所 Central Research Laboratory Fuj Iron and Steel Co., Ld.
}

子吸収断面皘が小さく放射線損賃の少いととが要求され る.これらの要求を全部渾足するような高張力鎬を開発 することが理想であるが，現実にはかなり困難である. 本研究化执いては原子炣用として試作された板厚 $30 \mathrm{~mm}$ の引張強さ $60 \mathrm{~kg} / \mathrm{mm}^{2}$ 以上を有する高張力鋼（以下 HT 60 銅と称する.） 4 種拉よび引張強さ $70 \mathrm{~kg} / \mathrm{mm}_{\mathbf{z}}$ 以上を有する高張力鍋（以下 HT 70 鋼之称する） 2 種計 6 鋼種について母材扰よび溶接継手の高温引張試験上ク リープ・ラプチャ試験を行ない種々比較検討した結果を 報告する．

\section{2. 供 試 鋼 材}

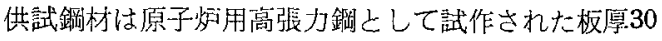
$\mathrm{mm}$ の HT 60 鋼 4 種（烓準鋼 3 種 6NA，6NB，6NC 扤 よび調質鋼 1 種 $6 Q$ ）占よび HT 70 鋼 2 種（調質鋼 $7 Q$ A，7QB）合部 6 種で，その製造履歷，化学成分ならび にオーステナイト結鼠粒度は Table 1 亿示すとおりで 
Table 1 Chemical analysis $(\%)$ of used steels

\begin{tabular}{|c|c|c|c|c|c|c|c|c|c|c|c|c|c|c|c|c|c|}
\hline \multirow{2}{*}{$\begin{array}{l}\text { Used } \\
\text { steel }\end{array}$} & \multirow{2}{*}{$\begin{array}{l}\text { Plate } \\
\text { thick- } \\
\text { ness }\end{array}$} & \multirow{2}{*}{$\begin{array}{l}\text { Alloying } \\
\text { element }\end{array}$} & \multirow{2}{*}{$\begin{array}{l}\text { Heat } \\
\text { treatment }\end{array}$} & \multicolumn{2}{|c|}{$\begin{array}{c}\text { Element } \\
(\%)\end{array}$} & \multicolumn{10}{|c|}{ (Upper value; ladle analysis, under value; check analysis) } & \multirow{2}{*}{$\begin{array}{l}\text { Ceq. } \\
(\%)\end{array}$} & \multirow{2}{*}{$\begin{array}{c}\text { A.G.S. } \\
\text { No. }\end{array}$} \\
\hline & & & & C & $\mathrm{Si}$ & Mn & $\mathrm{P}$ & $\mathrm{S}$ & $\mathrm{Cu}$ & $\mathrm{Ni}$ & $\mathrm{Cr}$ & Mo & V & $\mid$ other $\mid$ & $\begin{array}{l}\text { sol } \\
\text { Al }\end{array}$ & & \\
\hline $6 \mathrm{NA}$ & \multirow{2}{*}{$30 \mathrm{~mm}$} & $\mathrm{Mn}-\mathrm{Cr}-$ & $900^{\circ} \mathrm{CN}$ & .13 & .45 & 1.14 & .016 & .008 & - & - & .30 & .23 & .10 & - & .030 & .47 & \multirow{2}{*}{4} \\
\hline $\mathrm{N}$ & & Mo-V & $450^{\circ} \mathrm{CT}$ & .12 & .45 & 1.17 & .013 & .006 & - & - & .32 & .25 & .14 & - & .026 & .46 & \\
\hline 6 Z B & \multirow[t]{2}{*}{ " } & $\mathrm{Mn}-\mathrm{Mo}$ & $880^{\circ} \mathrm{CN}$ & .15 & .28 & 1.25 & .015 & .007 & .11 & 1.19 & .40 & .39 & - & - & - & .51 & \multirow{2}{*}{$6-7$} \\
\hline $\mathrm{N}$ & & $\mathrm{Ni}$ & $\mathrm{AC}$ & .15 & .28 & 1.34 & .011 & .006 & .11 & 1.15 & .02 & .31 & - & - & .025 & .49 & \\
\hline $6 \mathrm{NC}$ & \multirow[t]{2}{*}{$"$} & Mn-Mo- & $900^{\circ} \mathrm{C} \mathrm{AC}$ & .14 & .36 & 1.24 & .028 & .023 & - & .44 & - & .22 & .12 & - & - & .44 & \multirow[t]{2}{*}{7} \\
\hline $\mathrm{N}$ & & V & $650^{\circ} \mathrm{C}$ TAC & .15 & .35 & 1.28 & .029 & .020 & .10 & .47 & .08 & .21 & .10 & - & .013 & .45 & \\
\hline $6 Q$ & \multirow[t]{2}{*}{ " } & $2 \mathrm{H}$ type & $950^{\circ} \mathrm{C} W Q$ & .15 & .32 & .96 & .014 & .013 & .22 & .24 & .11 & .48 & - & - & - & .47 & \multirow{2}{*}{$5-9$} \\
\hline Q\&T & & -Mo & $680^{\circ} \mathrm{C} \mathrm{TAC}$ & .15 & .34 & .92 & .015 & .014 & .27 & .29 & .10 & .51 & Tr. & Ti Tr & .020 & .48 & \\
\hline 7QA & \multirow[t]{2}{*}{ " } & $\mathrm{Mn}-\mathrm{Cr}-$ & $930^{\circ} \mathrm{C}$ WQ & .12 & .40 & 1.09 & .017 & .012 & - & - & .43 & .48 & .10 & - & .037 & .53 & \multirow{2}{*}{6} \\
\hline$Q \& T$ & & Mo-V & $670^{\circ} \mathrm{CT}$ & .11 & .38 & 1.06 & .022 & .012 & - & - & .44 & .48 & .12 & - & .031 & .52 & \\
\hline $7 Q B$ & \multirow[t]{2}{*}{ " } & $\mathrm{Mn}-\mathrm{Cr}-$ & $880^{\circ} \mathrm{C}$ WQ & .14 & .30 & 1.04 & .015 & .009 & .25 & .44 & .59 & .46 & .06 & В 002 & .02 & .57 & \multirow{2}{*}{ 5-7 } \\
\hline Q\&T & & Mo-B & $\left|\begin{array}{r|}670-680 \\
{ }^{\circ} \mathrm{C} \text { FC }\end{array}\right|$ & .15 & .31 & 1.11 & .015 & .010 & .24 & .44 & .56 & .46 & .06 & $\mid$ B $002 \mid$ & .02 & .59 & \\
\hline
\end{tabular}

Remarks.......N ; Normalizing. T; Tempering. WQ; Water Quench. AC; Air Cooling. FC; Forced Cooling. $\mathrm{Ceq}=\mathrm{C}+1 / 6 \mathrm{Mn}+1 / 24 \mathrm{Si}+1 / 40 \mathrm{Ni}+1 / 5 \mathrm{Cr}+1 / 4 \mathrm{Mo}+1 / 40 \mathrm{~V}$

A.G.S. Austenite Grain Size

ある。溶解炉は $6 \mathrm{NC}$ 鋼のみ $60 \mathrm{t}$ 平多で, 他は 10 20 t エルー炉または電気炉である。6NAおよび 7QA 鋼はア ルミキルド鋼， $6 \mathrm{Q}$ 鋼は $\mathrm{Mn}-\mathrm{Si}$ キルド鋼，7QB 鋼は陵 素吹精後白涬法により脱酸を行なった鋼である．熱処理 としては, 6NB 鋼のみは単純な焼ならしが行なわれ， $6 \mathrm{NA}$ および $6 \mathrm{NC}$ 鎆は焼ならし後空冷またはある程度強
制冷却が行なわれ，さらに低温で焼すどされた。 $6 \mathrm{Q}$, 7QA および 7QB 鋼は水燒入れ後もどされたいわゆる調 質鋼である。いずれの鐥種も Mn および Mo が入って おり，6Q 鋼は他の合金元素をほとんど含まず，6NB 鋼 はこれに $\mathrm{Ni}$ を添加, $6 \mathrm{NC}$ 鋼はVを添加, 6NA および $7 \mathrm{QA}$ 鋼は $\mathrm{Cr}$ と $\mathrm{V}$ を添加，7QB鎆は $\mathrm{Cr}$ および $\mathrm{B}$ を添
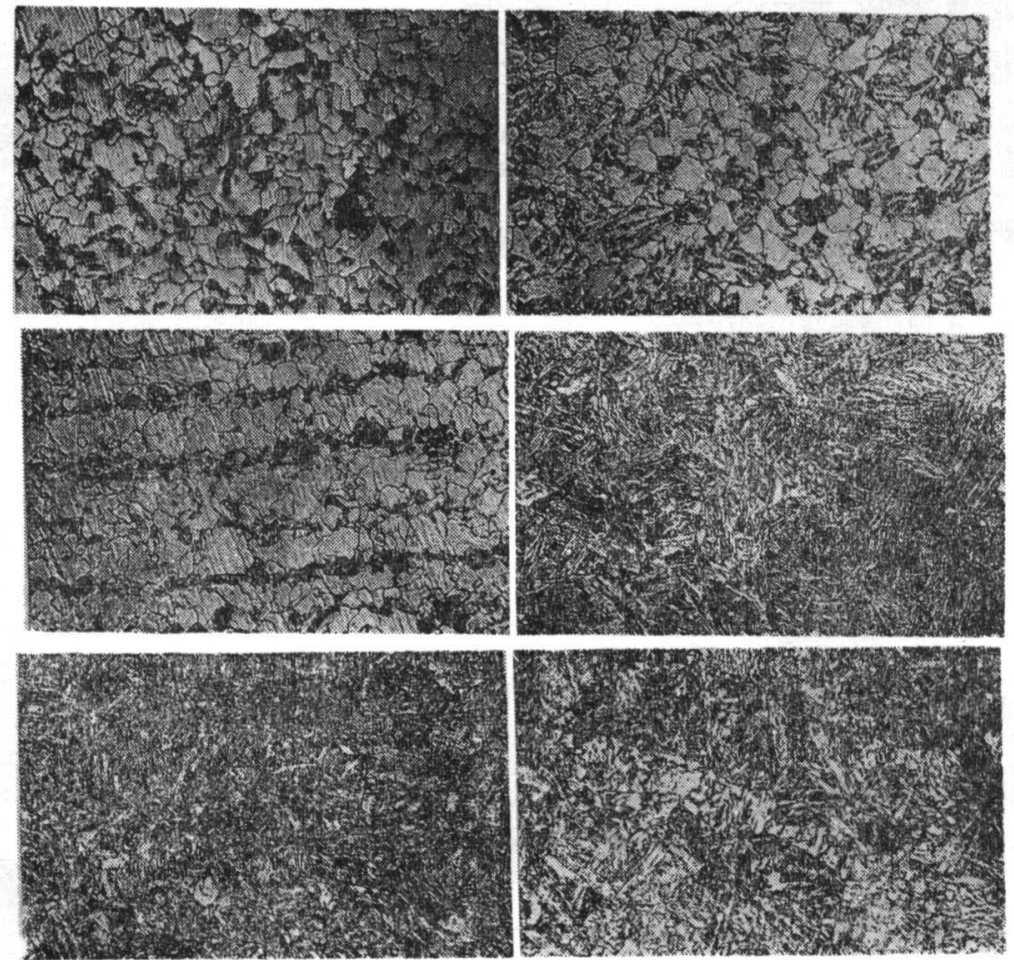

Photo. 1 Microstructures of used steels as received $(\times 400)$ 
Table 2 Chemical analysis $(\%)$ and mechanical properties of weld metals for used steels

\begin{tabular}{|c|c|c|c|c|c|c|c|c|c|c|c|}
\hline \multirow{2}{*}{$\begin{array}{l}\text { Used } \\
\text { steels }\end{array}$} & \multicolumn{7}{|c|}{ Element $(\%)$ (Check analysis) } & \multirow{2}{*}{$\begin{array}{c}\text { Yleld } \\
\text { point } \\
\left(\mathbf{k g} / \mathrm{mm}^{2}\right)\end{array}$} & \multirow{2}{*}{$\begin{array}{c}\text { Tensile } \\
\text { strength } \\
\left(\mathrm{kg} / \mathrm{mm}^{2}\right)\end{array}$} & \multirow{2}{*}{$\begin{array}{c}\text { Elotgation } \\
\text { GL } 50 \\
(\%) \mathrm{mm}\end{array}$} & \multirow{2}{*}{$\begin{array}{c}\text { Reduction } \\
\text { of area } \\
(\%)\end{array}$} \\
\hline & C & $\mathrm{Mn}$ & $\mathrm{Si}$ & $\mathbf{P}$ & $\mathbf{S}$ & $\mathrm{Ni}$ & Mo & & & & \\
\hline $6 \mathrm{NA}$ & .09 & .84 & .49 & .018 & .019 & 1.02 & .24 & 55.6 & 63.7 & 30.3 & \\
\hline $6 \mathrm{~N} \mathrm{~B}$ & .08 & 1.06 & .46 & .021 & .012 & .72 & .23 & 61.7 & 68.6 & 25.2 & 66.0 \\
\hline $6 \mathrm{NC}$ & .07 & 1.10 & .62 & .011 & .012 & .62 & .21 & 53.0 & 64.7 & 29.4 & 72.3 \\
\hline $6 Q$ & $" \prime$ & $" \prime$ & $" \prime$ & $\prime \prime$ & $n$ & $" 1$ & $" \prime$ & " & $"$ & " & $"$ \\
\hline $7 \mathrm{QA}$ & .07 & .92 & .41 & .018 & .016 & 2.89 & .31 & 61.7 & 73.2 & 25.0 & 55.7 \\
\hline $7 \mathrm{QB}$ & .07 & 1.00 & .65 & .008 & .010 & 2.63 & .26 & 62.2 & 75.1 & 26.2 & 66.7 \\
\hline
\end{tabular}

扣している・レードル分析值よチエック分析值はかなり よく一致しており，宸素当星は HT 60 鈯が0.43 0.51, HT 70鋼は 0.52〜0.59の籍囲にある.乙れら各鋁種受入 扎状態の顕微鏡組織は Photo 1 の打りである. 6NA, $6 \mathrm{NB}$ および $6 \mathrm{NC}$ 鋸はだいだいフェライトとパーライト からなる組織で，6NA鋼はパーライトが一様に分散し， $6 \mathrm{NB}$ 鋼はやや過熱組織を呈し，6NC 鋼はパーライトが

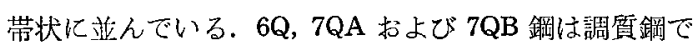
あるので焼もどしマルテン組織を呈している.

以上の各鋼種溶接継手試験片を製作するのに使用した 溶接炉は Mn-Ni-Mo 系の被㠅アーク溶接棒で溶接金属
の化学成分扣よび機械的性筫はTable 2 に示したよおり である．なお機械的性質は溶接したままのものである。

\section{3. 試 験 片}

母材試験片については板厚 $30 \mathrm{~mm}$ の供試鋼材より怠 温引張試験は JIS 4 号丸棒武験片（L/D=50 mm/10mm =5）を, クリープ・ラプチャ試験はFig. 1 (c) に示 す試験片（L/D=30 mm/6 mm=5）を製作しそれぞれ 試験に供した．溶接継手試験片については同様に板厚 $30 \mathrm{~mm}$ の供試鎘材に Fig. 2 の条件で㔖合女溶接を行な い，Fig. 3 に示拉置から Fig. 1 (a) および (b) に示

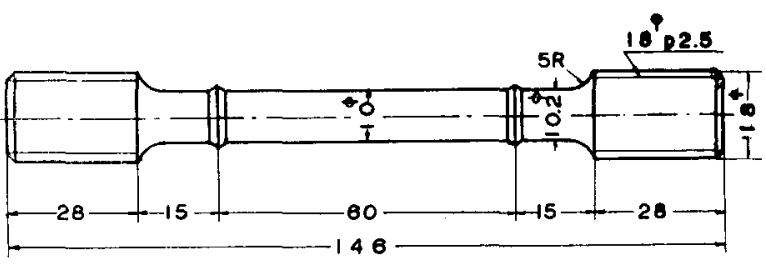

(a) Specimen for Tensile Test of High Temperature.

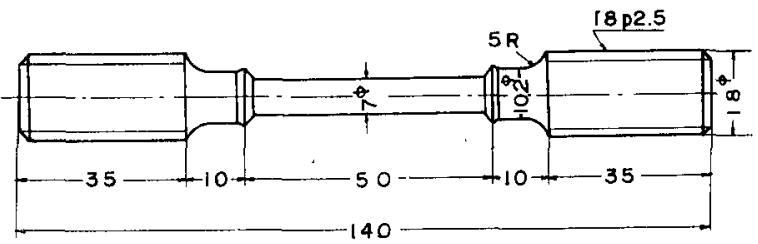

(b) Specimen of Weided Joint for Creep Rupture Test.

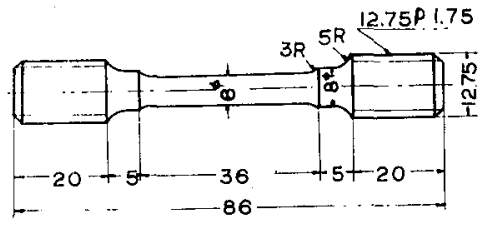

(c) Specimen of Base Metal for Creep Rupture Test.

Fig. 1 Size of specimens for tensile test at high temperature and creep rupture test 


\begin{tabular}{|c|c|c|c|c|c|}
\hline $\begin{array}{l}\text { Used } \\
\text { Steel }\end{array}$ & Type of Bevel & $\begin{array}{l}\text { Diameter } \\
\text { Iof } \\
\text { Electrode }\end{array}$ & \begin{tabular}{|l|} 
Welding \\
Position
\end{tabular} & $\begin{array}{l}\text { Preheating } \\
\text { Temp. }\left(^{\circ} \mathrm{C}\right)\end{array}$ & $\begin{array}{l}\text { Welding } \\
\text { Current (A) }\end{array}$ \\
\hline $6 \mathrm{NA}$ & & $4 \sim 5^{\stackrel{\phi}{\mathrm{tm}}}$ & $\begin{array}{l}\text { Flat } \\
\text { Welding }\end{array}$ & 200 & $\frac{160}{200}$ \\
\hline $6 \mathrm{NB}$ & & $4 \sim 5 \mathrm{~mm}$ & $\begin{array}{l}\text { Flat } \\
\text { Welding }\end{array}$ & 200 & $\frac{160}{200}$ \\
\hline $6 \mathrm{NC}$ & & $4 \underset{\mathrm{mm}}{\phi}$ & $\begin{array}{l}\text { Fat } \\
\text { Welding }\end{array}$ & No & $\widetilde{140}_{175}$ \\
\hline $6 \quad Q$ & & $4 \sim 5 \mathrm{~mm}$ & $\begin{array}{l}\text { Flat } \\
\text { Welding }\end{array}$ & 100 & $\frac{180}{240}$ \\
\hline $7 Q A$ & & $4 \stackrel{9 m}{m}$ & $\begin{array}{l}\text { Flat } \\
\text { Welding }\end{array}$ & 100 & $\frac{140}{175}$ \\
\hline $7 Q B$ & & $4 \sim 5_{\mathrm{mm}}^{\phi}$ & $\begin{array}{l}\text { Flat } \\
\text { Welding }\end{array}$ & 200 & $\frac{180}{240}$ \\
\hline
\end{tabular}

Fig. 2 Welding conditions for welded joints of used steels

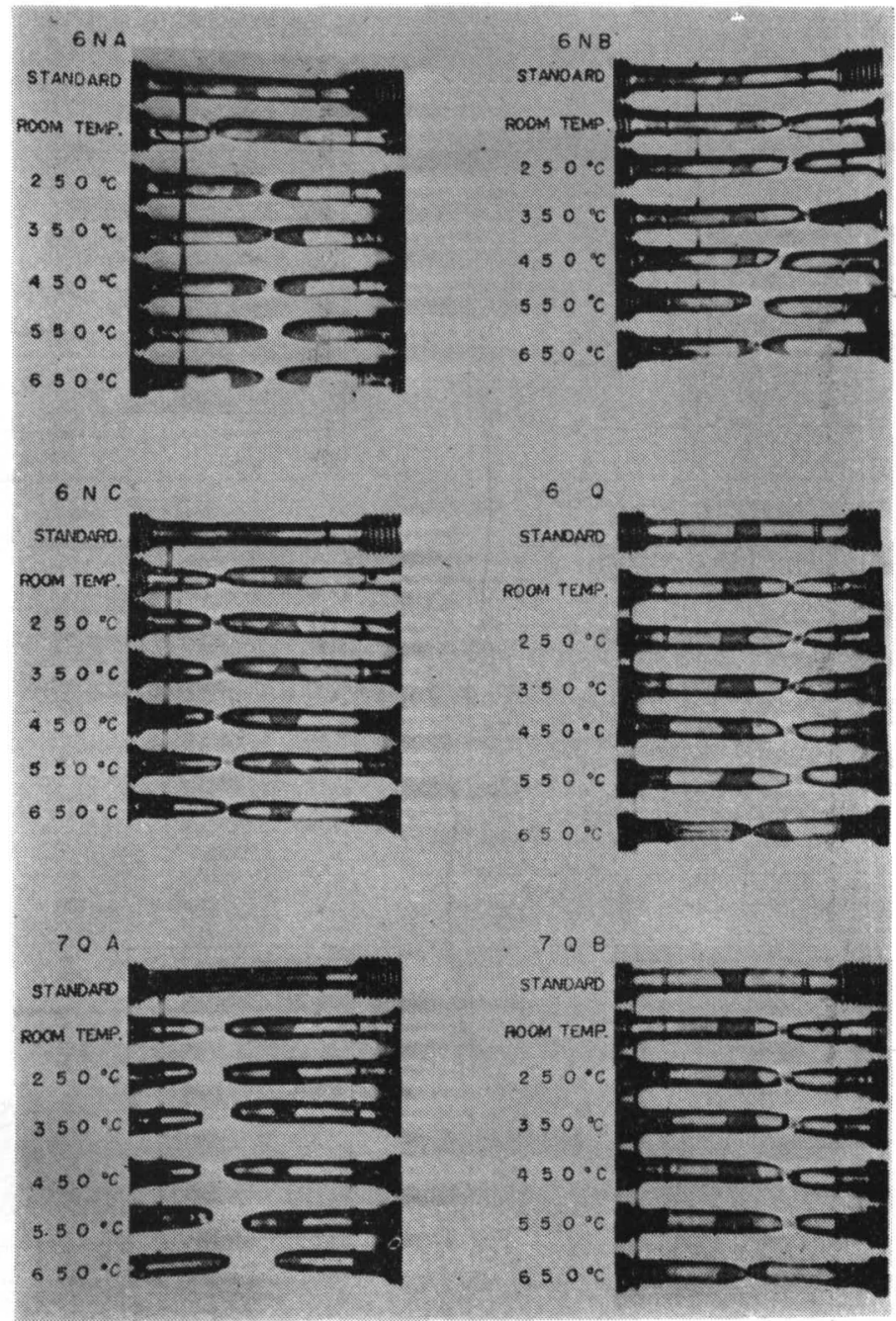

Photo. 2 Photographs of region fractured for tensile test at high temperature of welded joints 


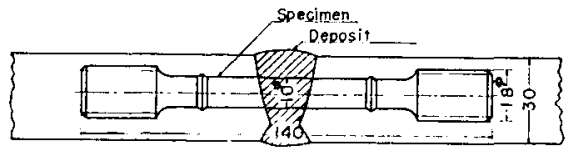

Fig. 3 Position of the specimen in welded joint

したような溶接継手試験片（高温引張試験片； $\mathrm{L} / \mathrm{D}=60$ $\mathrm{mm} / 10 \mathrm{~mm}=6$, クリープ・ラプチャ試験片； $\mathrm{L} / \mathrm{D}=70$ $\mathrm{mm} / 10 \mathrm{~mm} /=7)$ を製作し，それぞれの試験に供した。 なお母材試験片と溶接継手試験片の寸法が異なっている のは試験機の容量および溶接継手部における溶接金属と 熱影響部の箅囲を考虑したためである.

\section{4. 実 験 方 法}

供試鋼材全 6 種について高温引張およびクリープ・ラ プチャ試験を下記の条件で実施した。

\section{1 高温引張試験方法}

高温引張試験においては試歌温度を窒温 $\left(18^{\circ} \mathrm{C}\right), 250$,
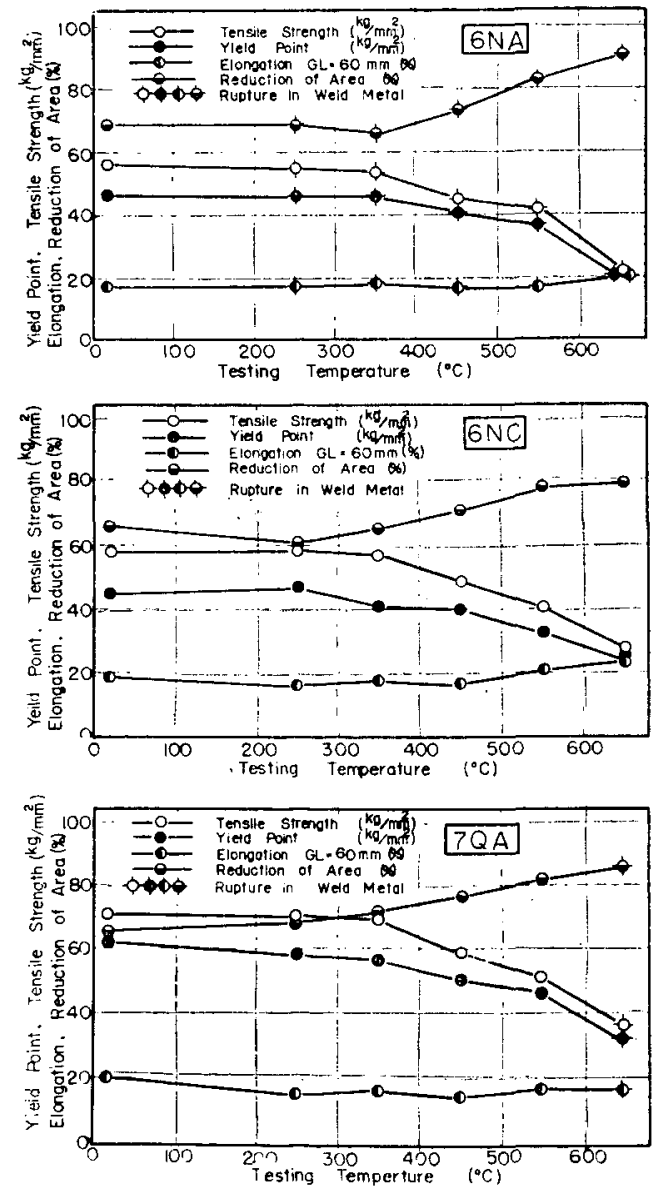

$350,450,550,650^{\circ} \mathrm{C}$ の 6 温度亡し，それぞれの温度で 引張試験を行ない，除伏点 $(0.2 \%$ の永人堽を生ぜしめる 応力)，引張強さ，伸びおよび絞りを求めた。また溶接 継手試験片については破断個所毛観察した，溶接継手試 験片は各鋼種とも溶接のままの状態で試験に供した。な お盰材高温引張試験估供試鏋材製造会社て実施したもの である。

\section{2 クリープ・ラプチャ試験方法}

クリープ・ラプチャ試験仙わいては母材尔よび溶接継 手試験片と屯 $400^{\circ} \mathrm{C}$ の温度で試験を行ない，応力と破斨 㭙間の関係を求めた。なお溶接継手試験片は各鋼種と屯 溶接のままの状態で試験に供した。

\section{5．実験結果および考察}

\section{1 高温引張試験}

試験に供した全 6 鍋種の溶接継手高温引張試験綕果を 各鋼種別に示したのが Fig. 4 で，その切断状況を示し
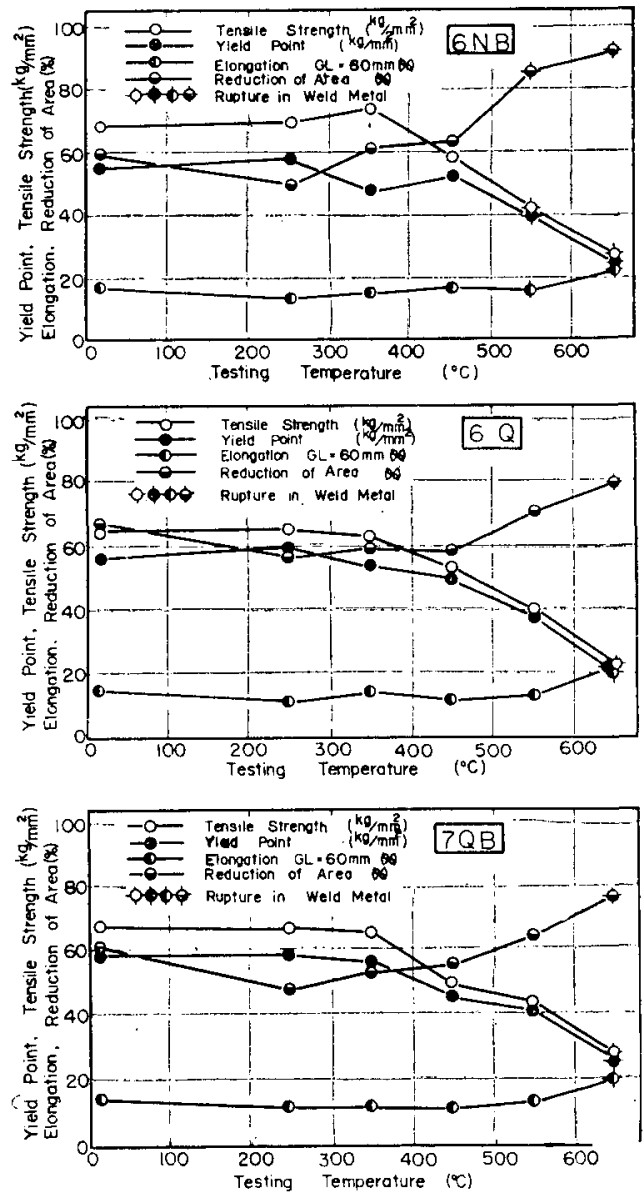

Fig. 4 Mechanical properties of used steels at high temperature tensile test 
たのが Photo 2 である。これらの結澘によると試験温 度が $350^{\circ} \mathrm{C}$ までの引張武験結果は室温の場合にくらべ てあまり変らないようである。また一般に試験温度が高 くなるにしたがい，切断個所は母材部より溶接金属部へ 移行しているとよあ Photo 2 より明らかである. 各鋼 種の溶接金属部で切断する温度は Table 3 のよおりで

Table 3 Temperature of rupture in weld metal for used steels

\begin{tabular}{c|c|c|c|c|c|c}
\hline Used steel & $6 \mathrm{NA}$ & $6 \mathrm{NB}$ & $6 \mathrm{NC}$ & $6 \mathrm{Q}$ & $7 \mathrm{QA}$ & $7 \mathrm{BB}$ \\
\hline Temperature & $<25^{\circ} \mathrm{C}$ & $>55^{\circ} \mathrm{C}$ & - & $>650^{\circ} \mathrm{C}$ & $>650^{\circ} \mathrm{C}$ & $>650^{\circ} \mathrm{C}$ \\
\hline
\end{tabular}

ある、なお $6 \mathrm{NC}$ 鋼はこの試験温度範圈 $\left(18 \sim 650^{\circ} \mathrm{C}\right)$ で は溶接金属部切断はみられなかった。

Fig. 5 は各鋼種について母材と溶接継手の高温引張 強さを比較したものである．以下各鋼種别に母状と溶接 継手の高温引張強さを比較検討する.

6NA 鋼は母材の高温引張試験が 鋼材不足のためでき なかったので浴接継手と比較はできない，しかし Table 3 に示したようにきわめて低い試験温度 $\left(250^{\circ} \mathrm{C}\right)$ で溶接 金属部切断を起している。このことから $6 \mathrm{NA}$ 鋼溶接継 手に使用した被㠅アーク溶接棒は母材に対して溶接金属
が高温度において出度不足であるととが推察される。

Fig. 5 (a) は 6NB 鍓の場合である.この図によれば 車者の傾问はよく似ておりあまり差はみられない，母祆 および溶接継手上す $350^{\circ} \mathrm{C}$ 付近は室温の場合に比べて 引張強さ功増加している。これは青熱ぜい性によるもの と考えられる. この点を境にして母材と溶接継手の引張 強さの大小が逆になる。すなわち $350^{\circ} \mathrm{C}$ 以下の温度では 溶接継手は母材より大きいが， $350^{\circ} \mathrm{C}$ 以上の高温になれ ば逆に溶接継手の引張強さは低下し，その低下の割合は 高温度になるほど大きい. Table 3によればこの 6NB 鋼の溶接金属部で切断する温度は $550^{\circ} \mathrm{C}$ 以上である．以 上のととから溶接金属は母材に比して高温になるにした がい強さの低下の割合が大きいことが推察される.

Fig. 5（b）は6NC 鍋の場合である. 傾向的に云えば 両者はほぼ同様である，温度に対する両者の引張強さを 比較すれば溶接継手は室温の場合を除き他はすべて母材 の場合より引張強さは大きい. Table 3 によればての $6 \mathrm{NC}$ 鋼は本試験温度範囲 $\left(18 \sim 650^{\circ} \mathrm{C}\right)$ では溶接金属部 切断は生じなかった。これらのととから材の高温引張 強さが溶接金痋に比べて小さいことが推察できる.

Fig. 5 (c)，(d) および（e）はそれぞれ 6Q，7QA お よび 7QB 鋼の場合である。これらの図によればての3

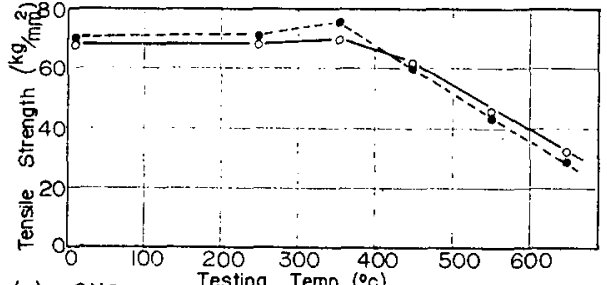

(o) $6 \mathrm{NB}$

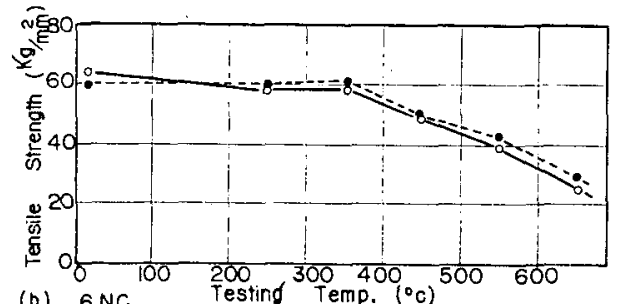

(b) $6 \mathrm{NC}$

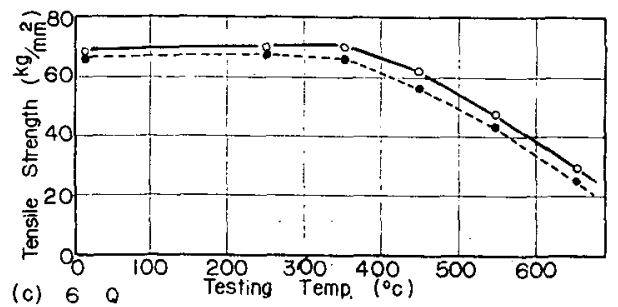

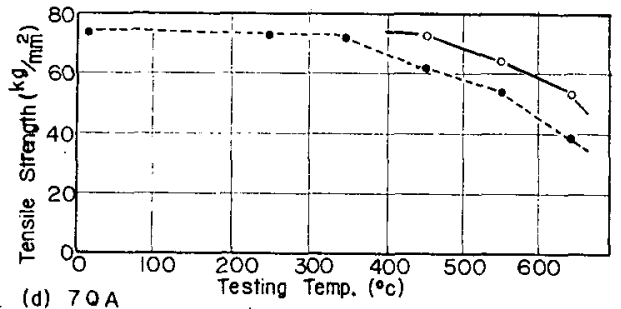

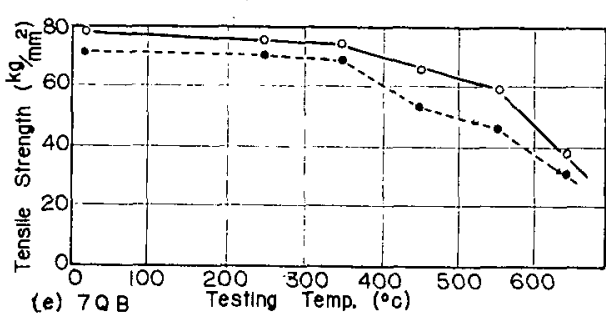

(e) $70 \mathrm{~B}$

Remorks:

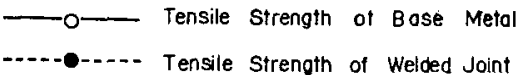

Fig. 5 Comparison of tensile strength at high temperature for base metals and welded joints of used steels 


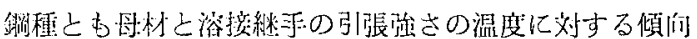
はほぼ间桃であり，いずれむ溶㑕継可の引張㤝さは母材

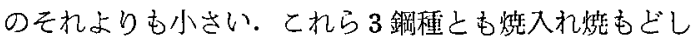
のいわゆる調質鋼である。これが急熱急冷の溶接熱サイ クルを受けその調質郊果が失われ，このために前述のよ うに溶接継手の引張強さは册材のそれに比べて小さくな るものと考えられる。拉 Table 3によればとれら 鋼種はいずれも $650^{\circ} \mathrm{C}$ で溶接金属部切断を生じている。

引張試験の結果伸びにあまり大きな変化はみられず， また各鈴種についての比較が困難なので，絬果を Fig. 6

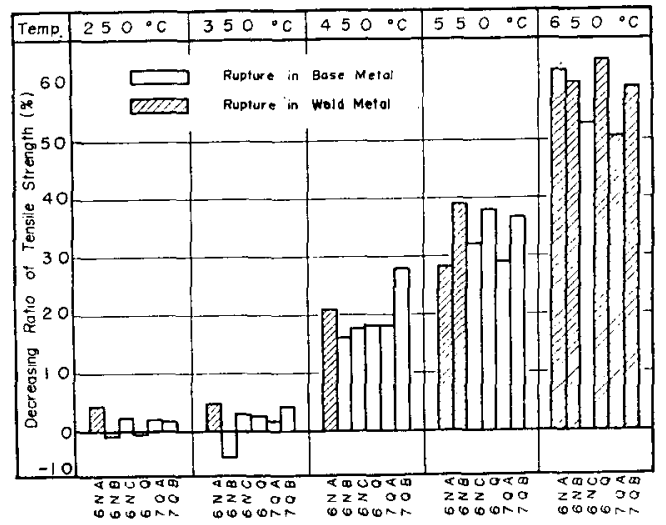

Fig. 6 Decreasing ratio of tensile strength of welded joints at high temperature $\left(\sigma_{T}\right)$ to the one at room temperature $\left(\sigma_{0}\right)$ : $\left(\sigma_{0}-\sigma_{T}\right) / \sigma_{0} \times 100 \%$

のように各鋼種の溶接継手引張強さの温度に対する低下 率で溙グラフにより整理した。 引張強さの低下率として

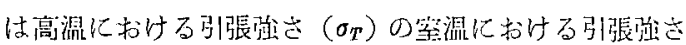
$\left(\sigma_{0}\right)$ に対する娍少率で表わした。すなわち，

低下率 $=\left(\sigma_{0}-\sigma_{\boldsymbol{T}}\right) / \sigma_{0} \times 100 \%$

を絎㛙にとった。図中斜線部分は溶接金属部における切 䉼を示している。

この瓦は各供試鋼材溶接継手について，その高温にお ける引張強さの室温におけるをれに対する低下率を各試 験温度が比較できるようになっている、たとえば試験温 度 $350^{\circ} \mathrm{C}$ の場合については $6 \mathrm{NA}$ 鋽は $4.77 \%$ の娍少, $6 \mathrm{NB}$ 鋼は $6.42 \%$ 増加, $6 \mathrm{NC}$ 鋼は $2.62 \%$ 娍少，6Q鋼 は $2.40 \%$ の減少，7QA鑶は $1.54 \%$ の減少，7QB 鋸は4.62 $\%$ の隇少で 6NA 鋼がすっとも引張強さの低下が大きく 李っと悪いととを示している. 以下 $7 \mathrm{QB}, 6 \mathrm{NC}, 6 \mathrm{Q}$, 7QAの順に低下率が小さくなっていることがわかる，ま た 6NB 鐸は逆に增加しているが，てれは前述の青熱ぜ い性の影響と考えられる. 同様に試験温度 $450^{\circ} \mathrm{C}$ の場 合については 6NA，6NB，6NC 6Q，7QA，7QB 鋼の低 下率はそれぞれ 20.8, 15.6, 17.4, 17.9, 17.8, 27.9 7QB 鋼がもっとも大きく低下している．以下 $6 \mathrm{NA}, 6 \mathrm{Q}$, 7QA，6NC，6NB の順に強さの低下率は小さい。 またこ の図より各鎯種とも $350^{\circ} \mathrm{C}$ まではその強さの低下率は わずか $5 \%$ 以下であるが $450^{\circ} \mathrm{C}$ になると $15 \%$ 以上急 に增㧈しているのでてれら供試鋼材は $450^{\circ} \mathrm{C}$ 付近の温度 で軟化が始まるととが想像される。 Fig. 6 より明らか なように溶接金属部におりる切断は 6NA 鋼を除いて, この軟化温度すなわち $450^{\circ} \mathrm{C}$ 付近以上で生じている. また Table 3 に示したように煍準鉬 6NB 鋼の溶接金 閩部における切断は $550^{\circ} \mathrm{C}$ 以上があるのに刘し，調貿

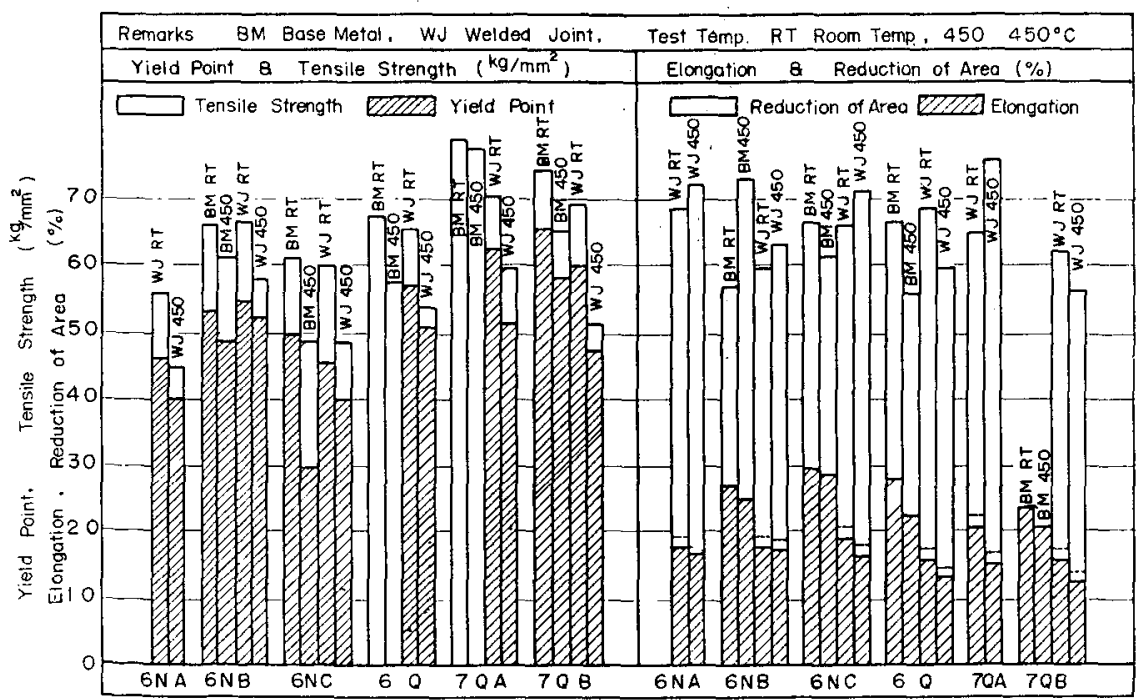

Fig. 7 Comparison of mechanical properties at $450^{\circ} \mathrm{C}$ and room temperature for used steels 
鋼 6Q，7QA，7QB 鋼はいずれも $650^{\circ} \mathrm{C}$ 以上の高い温度 を示している.

一般に前述のように供試鋼材は $450^{\circ} \mathrm{C}$ 付近で軟化が 绐まり，また実際の構造物汇おいてす鋼材の使用温度は $400^{\circ} \mathrm{C}$ 以下之考えられるので各鋼種について $450^{\circ} \mathrm{C}$ に おりる引張試験結果と室温における結果とを比較した。

Fig. 7 はこの関係を示した棒グラフである. 図の綐軸 は降伏点，引張強さ，伸びおよび较りを表わしている. 図の左半分は各鋼種別に 母材 $(\mathrm{BM})$ および溶接継手 （WJ）の室温と $450^{\circ} \mathrm{C}$ における降伏点と引張強さを表 わしたもので斜線を施した棒グラフが降伏点を示してい る. 6NA 鋼母材は前述の上うに鋼材不足のため高温引 張試験ができなかったものでてこには示していないま た $6 \mathrm{Q}$ および $7 \mathrm{QB}$ 鐦の母材は降伏点の測定ができなか った。一般に各鋼種と屯溶接継手は母材に比べて室温お よび $450^{\circ} \mathrm{C}$ における引張強さは低いようである。また $450^{\circ} \mathrm{C}$ における引張強さの室温に対する低下も溶接継手 のはうが母材より大きいようである. HT 60 鋁（6NA， 6NB，6NC，6Q 銅）について比較する上 $6 \mathrm{NB}$ 拉よび 6Q)

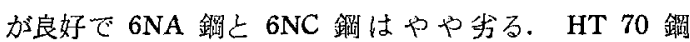
(7QA，7QB）について比較する之母材，溶接継手とむに $7 \mathrm{QA}$ 鋼のほうが良好で, $450^{\circ} \mathrm{C}$ に抢ける強さの室温に 対する低下す小さい。

Fig. 7 の右半分は伸びと絞りの図で斜線を施した棒グ ラフが伸びの大きさを示している。なお 6NA と7QA 鋼母材の場合伸び測定ができなかったのでここには示し ていない，伸びは前述のように母材試験片は $\mathrm{L} / \mathrm{D}=50$ $\mathrm{mm} / 10 \mathrm{~mm}=5$ であり，溶接継手試験片は $\mathrm{L} / \mathrm{D}=60$ $\mathrm{mm} / 10 \mathrm{~mm}=6$ で算出したあのでこのままでは比較する ことはできない，比較するためにはある標準の值に衡算 しなけ机ばならない，そこで現在 WES 規格の低温構造 用銅板判定規準に採用されている换算式》(1)式索用いて 本試験における母材と溶接継手の伸びを比較することに する：

$$
\varepsilon^{\prime}=2 \varepsilon(\sqrt{\mathrm{A}} / \mathrm{L})^{0.40}
$$

ここに $\varepsilon^{\prime}=$ ある試験片についての伸び

$\mathrm{L}=$ 標点距離, $\mathrm{A}=$ 断面積, $\mathrm{d}=$ =直径

$\varepsilon ; \mathrm{L} / \mathrm{D}=\mathbf{5}$ 亿おりる伸び

本試験沈おいて母材の場合は $\mathrm{L} / \mathrm{D}=5$ であるからそ のままでよいが溶接継手の場合は， $L / D=6$ であるから 母材上同じ $\mathrm{L} / \mathrm{D}=5$ の場合の伸びに 换算しなければな らない. そこで(1)式を用いて $\mathrm{L} / \mathrm{D}=5$ と $\mathrm{L} / \mathrm{D}=6$ の件

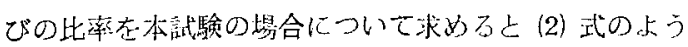
になる。

$$
\frac{\varepsilon^{\prime}}{\varepsilon^{\prime \prime}}=\left(\frac{\sqrt{A^{\prime}} / L^{\prime}}{\sqrt{\overline{A^{\prime \prime}} / L^{\prime \prime}}}\right)^{0.40}
$$

ここに $\varepsilon^{\prime}, A^{\prime}, L^{\prime}$ は $\mathrm{L} / \mathrm{D}=5$ の場合の伸び, 断面積, 標点距離を表わし， $\varepsilon^{\prime \prime}, A^{\prime \prime}, L^{\prime \prime}$ は $L / D=6$ の場合の伸 び, 断面栍, 標点距離を表わしている。母材試験片と溶 接継手試験片の直径は等しいので(2) 式で $A^{\prime}=A^{\prime \prime}$ とお ける.すなわち伸びの比は（3）式のようになる。

$$
\varepsilon^{\prime} / \varepsilon^{\prime \prime}=\left(\mathbf{L}^{\prime \prime} / \mathrm{L}^{\prime}\right)^{0.40}
$$

$\mathbf{L}^{\prime \prime}=60 \mathrm{~mm}, \mathrm{~L}^{\prime}=50 \mathrm{~mm}$ を代入すれば本試験の場合の伸 び比が求まる.

$$
\varepsilon^{\prime} / \varepsilon^{\prime \prime}=(60 / 50)^{0.4}=1.08
$$

すなわち $\mathrm{L} / \mathrm{D}=6$ の場合の伸びに 1.08 を乘ずれば L $/ \mathrm{D}$ $=5$ の場合の伸びに換算される。. Fig. 7 に戈いて，伸 びを示した棒グラフの上に点線で示したのが上式で撸算 した値でおる、たとえば 6NB 鋼の室温における場合换 算された佃びは $18 \% \times 1.08=19.4 \%$ である．ての换算さ れた仲びで母材と溶接継手を比較するといずれの䣄種も 溶接継手の他びは母材より小さい。また各供試鋼材同梯 に母材拉よび溶接継手のいずもが $450^{\circ} \mathrm{C}$ における伸び は室温の場合より小さい。しかし絞りは逆沉 $450^{\circ} \mathrm{C} の$ 埸合が大きい值を示している。

以上の結果を総合すると，高張力鋼を高温で使用する 場合，概して単純な焼準処理を施した甄材すなわち $\mathrm{A}_{3}$ 変態点以上に加熱し空泠したままで，あとで烧むどし观 理を行なかないものが望ましいととが推察できる。

\section{2 クリープ・ライプチャ試験}

試験に供した全 6 鋼種の母材拈よび溶接継丁について $400^{\circ} \mathrm{C}$ でクリープ・ラプチャ試験を行なった．Fig. 8 は

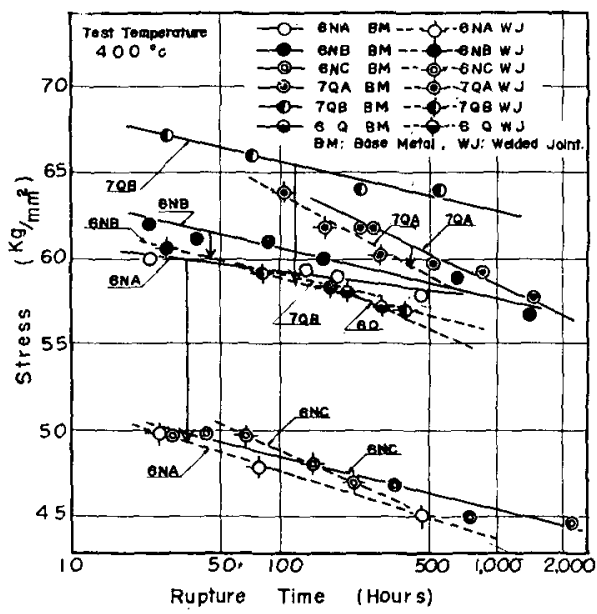

Fig. 8 Stress-rupture time lines of base metals and welded joints for used steels

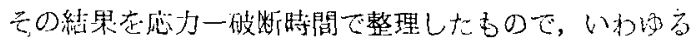
クリープ・ラプチャ特性図である。图中実線と极線はる れぞれ母材試験片および溶接継手試験片による結然を示 
したむのである。また実線から破線へ引いた印は溶接 継手クリープ・ラプ手ャ強さが母材の場合に比べていか に低下しているかを示したものである。たとえば6NA， $7 \mathrm{QB}$ の溶接継手は母材の場合に比へて，それぞれ 11 お よび $8 \mathrm{~kg} / \mathrm{mm}^{2}$ 但下している. Fig. 9 は $6 \mathrm{NA}$ 鋼につ

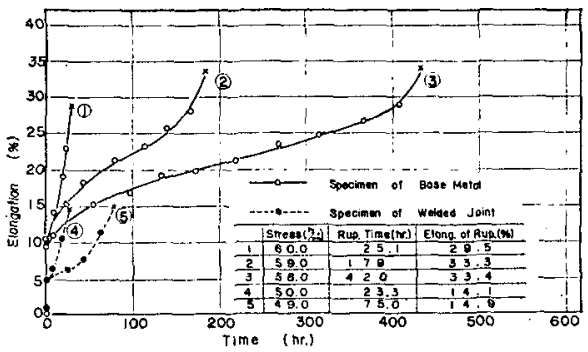

Fig. 9 Creep curves at $450^{\circ} \mathrm{C}$ for base metal and welded joint of 6NA steel

いてのクリープ伸び線図である。実線は母材試験片の場 合，碳線は溶接継手の場合である，今母材之溶接継手に つて，その破断伸びを便宜的に算術平均して比較する と母材の場合は $32.1 \%$ であり溶接継手の $14.5 \%$ に比べる と破断伸びはいちじるしく大きい.同様にして各鋼種の 母材乙溶接継手について，平均破断伸びを求めた結果が Table 4 である.'破断個所は Table 4 亿示したように

Table 4 Mean creep rupture elongation for base metals and welded joints of used steels

\begin{tabular}{c|c|c|c}
\hline Used stee1 & $\begin{array}{c}\text { Base metal } \\
\mathrm{L} / \mathrm{d}=5(\%)\end{array}$ & $\begin{array}{c}\text { Welded joint } \\
\mathrm{L} / \mathrm{d}=7(\%)\end{array}$ & $\begin{array}{c}\text { Position of } \\
\text { rupture }\end{array}$ \\
\hline & 32.1 & $14.5(17.6)$ & Base \\
6N A & 20.9 & $14.4(17.4)$ & Base \\
6N B & 27.2 & $18.0(21.8)$ & Base \\
6NC & 14.8 & $14.1(17.1)$ & Band \\
6 Q & 13.9 & $11.6(14.1)$ & Bond \\
7QA & 13.6 & $11.7(14.2)$ & Bond \\
7Q B & & &
\end{tabular}

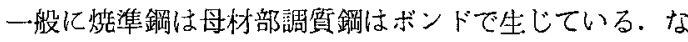
お伸び换算比を前節 (3) 式で求めると約 1.21 である.乙 の比率を乗じた値が表中（）で示した值である.

以上の結果加ら明らかなように一般に溶接継手のクリ 一プ・ラプチャ強さは母材の場合に比べて小さい，とく

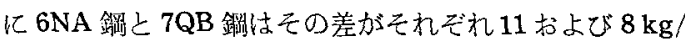

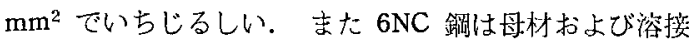
継手のいずれの場合む他鋼程に比べていちじるしく低い 值を示している。これは亶温引張の場合と同様に母材の

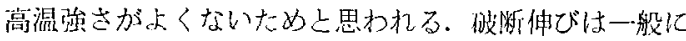

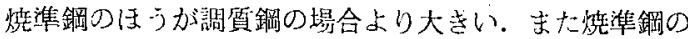
場合は溶接継手の国うが母材に比へて小さいが調質鋼は 逆に溶接継手の注うが大きい:てれは溶接に際し母材が 受ける急熱急冷の游しい熱サイクルで范むじし温度以上
に加熱されて溶接熱影響部の調質効果が失われ，破断伸 びが大きくなるむのと思わ机る。

各鎆種のクリープ・ラプチャ活さをを比較するために， Fig. 8 の結果をむとにして，500㭙間および 1000時間破 断応力を母材に溶接継棐の場合について各鋼種别に整理 して Fig. 10 に示す棒グラフで表わした.との図より前

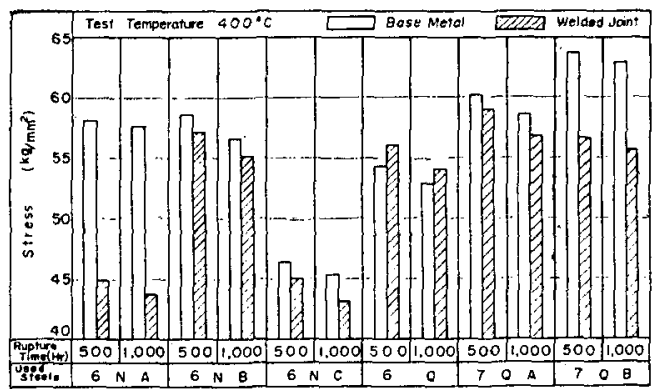

Fig. 10 Comparison of creep rupture strength of used steels at $500 \mathrm{hr}$ and $1,000 \mathrm{hr}$ ruptuie time

述の溶接練手のクリープ・ラプチャ強さが母材の湶合に 比して低いことがいっそう明らかである。ただ 6Q 錷の みは溶揬継手のほうが母忉の場合よりす大きくなってい るが，この理由は明らかでない，また $6 \mathrm{NA}$ 鐥と7QB 鎡 の溶接継手求よび $6 \mathrm{NC}$ 鋼の母材と溶接継手の埸合が他

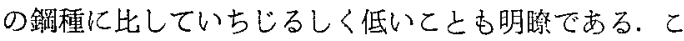
の図をむとにして各鋼種を比較してみる．HT 60 銷母 材の場合についてクリープ・ラプチャ強さを大きい順に 挙げると, $6 \mathrm{NB}$ 鋼, $6 \mathrm{NA}$ 鋼, $6 \mathrm{Q}$ 鋼, $6 \mathrm{NC}$ 鋼である.

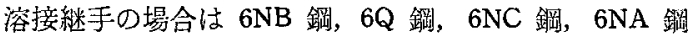
の順であるここの両方の結果を総合すると $6 \mathrm{NB}$ 鐦があ っ上あ良好である.これは他の HT 60 鋼が焼ならし後 低温焼むどし処理あるいは焼入れ焼むどしの調質処理を 拖しているのに対して単純な焼ならし姏理を行なった龬 種であるため高温で使用する際に生ずる烓委どし作用な よ゙の影響がまったくなく，また化学成分的に云ってるC が高く，Ni は1\%以上で Mo む3\%上 $6 \mathrm{Q}$ 鋼についで 多く入っており炭素当量屯他 3 鋼種に比べて高いためと 考えられる。しかし 6NB 鋼のように単純な焢準鋼であ る上，どうしても低温じん性の低下はさけられないの で，6Q 錩，6NA 鍓および 6NC 鎆のような調犋処理で このじん性の句上ほかる絬果になる2，したがって，高

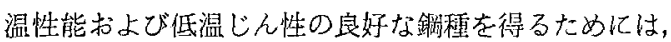

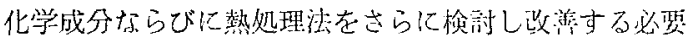
があるよ思才机る。

HT 70 鈯に执いては，母材のクリープ・ラプチャ強 さは7QB鍴のほうが7QA 鎆よりも大きいが，溶接継手 については逆に 7QB 䤫のはうが小さい。これは Table 
1 および Table 2 の化学成分をみて明らかなように 7QB 鋼は 7QA 政に比して Mo，にはあまり差がないが，C， $\mathrm{Ni}, \mathrm{Cr}$ 抢よび炭菜当量が多いためと考元られる。一方 溶接継手の場合はその溶接金属は逆に 7QA 頜のはうが $7 \mathrm{QB}$ 鋼に比して Ni および Mo が多いが, 破断位置は Table 4.亿示したように，いずれ屯ボンドである.この 個所は溶接熱影響のため組織的に不連続で，複雑な要素 を含んだ部分である．とのために，母材抢よご溶接金属 の性質のみから，乙の原因を考察するととは本実験の範 囲ではできない。

以上の結果を総合すると一般に炭素当粟が大きく，単 純な焼ならしをした釦のほうが，炭素当量が低く，熄なら

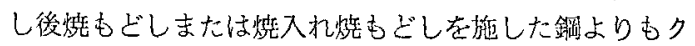
リープ・ラプチャ強さが大きいととがわかった。なお才 ーステナイト結晶粒の大小による差は諗められなかった

\section{3 高温引張試験結果よクリープ・ラプチャ 試験結果との比較}

前毁までの高温引張試験絬果とクリープ・ラプチャー

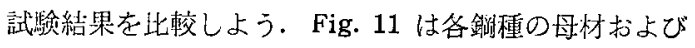

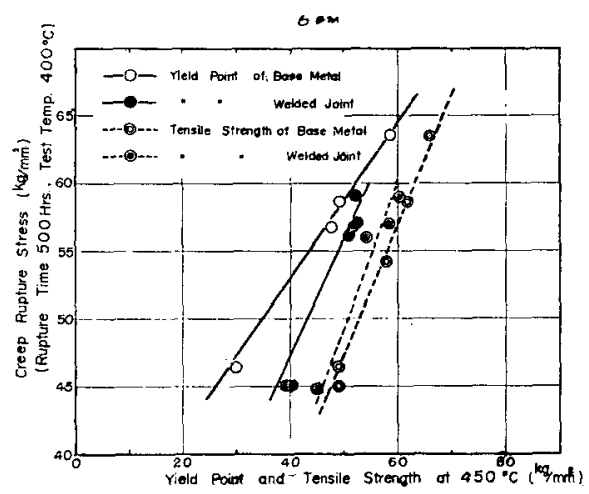

Fig. 11 Relation between yield point and tensile strength at $450^{\circ} \mathrm{C}$ and $500 \mathrm{hr}$ creep rupture strength at $400^{\circ} \mathrm{C}$

溶接継手の $450^{\circ} \mathrm{C}$ に㧍りる降伏点と引張強さを横軸に とり，てれと同じ鋼尾の母材扝よび溶接継乎の $450^{\circ} \mathrm{C} に$

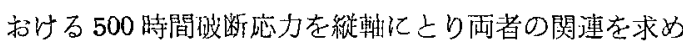
たものである. 図より高温引張強さおよびクリープ・ラ プチャ一強さとほほ直線関係にあるととがわかった。す なわち高温引張強さおよび降代点の大きなむのはクリー プ・ラプチャ一強さむそれに比例して大きい，母材につ いては比较的ばらつきが小さいが，溶接継手の場合はば らつきがかなり大きい，てれは母材の場合は組織的に一 応均一になっているが，溶接継手の場合は溶接施工に際 し，急熱急冷の激しい熱サイクルを受け溶接境界部近傍 には組織的に不安定な不連続部分ができるため，大きな 代らつき加生ずるものと思われる。また降伏点と引㖘強 さの直線は平行でなく，強さが大゙るなるにつれてての 間が涨くなっているのは一般的们滈张力鋼の降伏比は引 張強さが大きくなる゙はぼ大きくなるためと思われる。

\section{6. 結論}

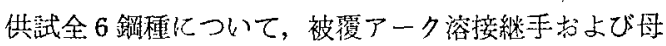
材の高温引張試験と, クリープ・ラプチャ試験を行なっ た.とれらの結果下記のことが判明した。

1．一般㣂温引張強さおよびクリープ・ラプチャ強 さは母忉よりも溶接継手のほうが劣るようである。また 伸びは高温引張試験の場合は全銷種とも溶接継手のほう が母材よりあ小さい．しかしクリープ・ラプチャ試験の 場合烸準鋼は高温引張試験の場合上同様であるが，調質 鋼の場合は逆に溶接継手の破断伸びは大きい。

2.母材および溶接継手の高温引張強さは調質鎦の場 合は $300^{\circ} \mathrm{C}$ から，烧準鋼の場合は $350^{\circ} \mathrm{C}$ 加らそれぞれ 減少し始める.

3. 溶接継于の高温引張試駼汇おりる切断個所は試験 温度が高くなるにしたがって母材部より溶接金属部へ移

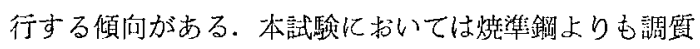
鏣のほうが高い温度で溶接金属部切断を生じた。

4. 高温引張試験の結果高張力鋁を高温で使用する場 合は単純な烧準鋼すなわち焼ならしのままで，あ上で烧 すどした処理を行なわないものがもっとも望ましく，つ

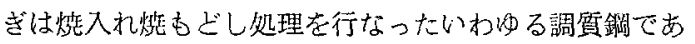
る.

5. クリープ・ラプチャ試験の結果 HT 60鍼，HT 70 銅乙屯化学成分的には $\mathrm{C}, \mathrm{Ni}, \mathrm{Cr}, \mathrm{Mot}$ 多く含有し, 炭 素当量が高いはう方破断处力は大きい，熱処理としては 高温引張試験の場合と同様単純な䡒準処理を行なったも のがもっ上も良好な結果を示した。

6. 高温引張とクリープ・ラプチャ試験の雨者の結果 を比較すると，高温引張強さおよび降伏点の大きいもの はそれに比例してクリープ・ラプチャ強さむ大きいよう である。

以上のように高温引張およびクリープ・ラプチャ試験

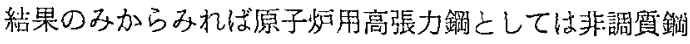
のほうが望ましいと考えられる。しかし単純な烍準銅で は低温じん性の低下はさけられないので，燒ならし後強 制朎却あるいは燒もどしなどの熱処理の土夫を行なって このじん性の向上をはかる必要がある．したがって高温 性能および低温じん性の両者を同時汇満足させる適正な 熱処理条件の選定は今後の重要な研究課題と考えられる

本実駼に際し協力していただいた八幡製鉄，富士製鉄 日本鋼管，日本製鋼，三菱製銿の各製鍓会社および新三 菱重工神戸造船所, 石川島播磨重工, 冨士電機川渏工場 三菱電機伊丹製作所, 三菱造船長崎造船所，只造船所の 各溶接施工会社ならびに金属材料技術研究所笑習生林踷 達雄君に深梖の謝意を表する。

\section{文献}

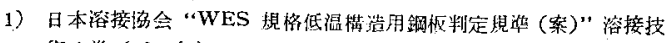
徒9 (1961年) 2 号 $1-7$.

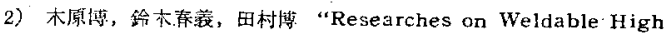

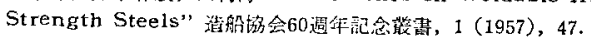

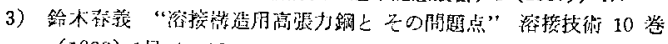
(1962) 1 녹 $1-16$. 